\title{
Portability Rewards And Avoidance Of Longevity Risk: Factors In The Growth Of Defined Contribution Plans
}

Beverley Hollingsworth, PhD, Fitchburg State University, USA Wei Wang, Fitchburg State University, USA

\begin{abstract}
The decline in defined benefit plans has been offset by a significant growth in defined contribution plans. An important consideration in this phenomenon lies in the fact that employees view this shift as a tradeoff between longevity risk and portability rewards. Companies are shifting from defined benefit plans to avoid the longevity risks associated with such plans. On the other hand, in some instances when given the option, employees chose defined contribution plans, due to the associated portability rewards where participants have a choice of rolling over, or transferring plans from former employers.. This paper examined research relevant in assessing factors contributing to growth in defined contribution with particular interest in $401(k) s$ and the relationship between investment returns, the availability of loans, and investment strategy that may affect plan growth. It is concluded that there is insufficient evidence for assuming a relationship between investment returns, loan availability and investment strategy and the growth of defined contribution plans.
\end{abstract}

Keywords: Investment returns, pension returns, defined contribution plan, longevity risk, portability rewards, pension plans.

\section{INTRODUCTION}

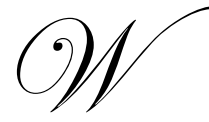

ith the increasing growth in 401(k)s extensive research on the topic of the growth of defined contribution plans, little is known about the factors that significantly influence such growth. We decided to investigate obvious factors that may influence this growth. The growth of defined contribution appears to have outpaced defined benefit plans. Several factors contributed to this growth. Over the last decades, Americans have witnessed significant changes in their retirement plans. These changes have a two-fold effect, where we have seen a decreasing number of employers offering defined benefit plans, while there is a significant shift to the number of employers offering defined contribution plans. This trend in pension plans translates into what can be described as a shifting of longevity risk from the employer to the employee. Most employees face the reality of this phenomenon, by accepting their responsibility in providing for their own retirement. We investigated this serious development and examined three factors and their impact on the growth of defined contribution plans with specific interest in 401k plans. The Investment Company Institute (2010) reports that as of September 2009, $\$ 15.6$ trillion was invested in total retirement assets. Of this amount, $\$ 3.9$ trillion was invested in employer-based defined contribution retirement plans with \$2.7 trillion represented investments in 401 (k) plans, and accounts for an increase of \$3.6 trillion and \$2.4 trillion respectively over the period June 30, 2009.

\section{DIFFERENCES BETWEEN DEFINED BENEFIT AND DEFINED CONTRIBUTION PLANS}

We will look at the basic differences or characteristics of both plans. For a defined benefit plan all assets invested in a plan are owned by the employer. In addition to the ownership, the employer also directs the investment activities and bears the risk associated with the plan. All benefits related to this defined benefit plan are guaranteed by the Pension Benefit Guaranty Corporation. (PBGC). Employees do not have access to funds except when they 
retire and are paid an annuity. If an employee dies, the plan allows for a survivor benefits for spouses. In a defined contribution plan, an employer makes a promise to contribute a specific amount such as a percentage of an employee's salary, and benefits are tied to the amount invested and the returns generated from the investment. Contributions comprise both employer and employee funds. A drawback to this plan may be that employees bear the risk when compared to defined benefit plans. A feature that may contribute to the growth of defined contribution plans may be the fact that employees do have access to funds prior to retirement, in the form of loans or hardship withdrawals.

\section{EVIDENCE OF CHANGES IN PENSION PLANS STRUCTURE AND GROWTH}

Data from the U.S Department of Labor report (2007) show that as of 2005, there were 65 million Americans enrolled in 401k plans that accounted for 2.4 trillion assets. In comparing the growth in defined benefit plans Gale, Papke, and VanDheri (1999) found that for the period 1975 to 1983, defined benefit plans rose from 103,000 to 175,000 , a 70 percent increase., and between the period 1990 -1995 those plans decreased by 101, 000 in 1990, and saw a further decreased to 70, 000. In contrast, defined contribution plans grew from 207, 000 to 623,000 for the year 1995. The authors suggest that the trend in $401(\mathrm{k}) \mathrm{s}$ replacing defined benefit plans is also evidenced in the fact that since 1995, for every defined benefit plan that is terminated, two 401k plans that are introduced.

\section{REASONS FOR CHOICE OF 401(K)}

Defined contribution plans have a lower administrative cost compared to defined benefit plans. It therefore, appears that the cost factor could be a significant determinant where both employees and employers would have a preference for defined contributions. Employers may prefer the cost effectiveness, and employees enjoy the taxdeferred saving and employer matching. Clark, Goodfellow, Shieber and Warwick (1999) reported that half of workers age 20-29 with earnings less than 15,000 made contributions to their $401(\mathrm{k})$ plans suggesting that $401(\mathrm{k}) \mathrm{s}$ could be a supplement as opposed to a replacement to defined benefits. Papke (1995) also found that 401(k) plans show good potential in the growth of retirement plans. Papke studied the participation and contribution effects of employer match. The results showed substantial increases in employee contributions when employer match increases to a moderate level, and a decrease in employee contributions when employer match increases to higher levels. Munnell and Perun (2006) reports that 401k plans have experienced a significant increase where all dimensions of plans have increased from between 30 and 50 percentage points of total defined contribution plans to approximately 90 percentage. Andrews (1992 points to the growth and suggests that it includes plans that are converted thrifts, while Kruse (1995) sees the growth in contribution plans as related the declining number of participants among firms that maintain defined benefit plans and only four percentage of growth resulting from termination of defined benefit plans. Other data on growth suggests that large proportions of defined contribution plan assets originated before 1982, (Engen, Gale and Scholz, 1996, b).

\section{EVIDENCE FROM PLAN RETURNS}

Several factors have been found to influence the growth of defined contribution plans. In view of this growth we focused our investigation on the investment returns, the availability of 401 (k) loans, and investment strategy as possible factors that may affect plan returns. We reviewed several studies and used data from Watson Wyatt Data Services and Employee Benefit Research Institute (EBRI). Employees in general feel that it is important for them to manage their own contribution plans. Citing the portability and longevity risk factors, employees consider self management as a way of avoiding the longevity risk to returns from defined contribution plans. We examined plan returns for both defined benefit and defined contribution for the period 1995 - 2006. Watson Wyatt (2007) reported that from a historical point of view, larger pension plans usually realize higher returns. This difference stems from the fact that in general larger plans have access to a variety of investment options and their experience and expertise in operations usually provides for the benefits of economies of scale. Using asset weighted median rates of returns, Watson Wyatt found that between 1995 and 2006, defined benefit plans outperformed 401k plans overall with a rate of 1.09 percentage (Figure 1). Most important, was the performance of defined benefit plans, whose performance was significant during the years 2003 through 2006. This is of added significance since this period represents a downward cycle in market conditions. When the data is disaggregated and weighted by size, 
results indicate that defined benefit plans falling under the largest one sixth, reported an overall higher return of 1.21 percentage points over defined contribution plans for the period 1995 through 2006 , Figure 1a). For plans accounting for the largest one half of plans weighted by median returns, defined benefit outperformed defined contribution plans by 0.82 percentage point (figure 2). Plans representing the smallest one sixth showed that defined contribution plans outperformed defined benefit plans by 1.03 percentage points, (figure 2a). In analyzing the data, there is support that higher returns were realized from the larger defined benefit plans compared to those of the smaller defined contribution plans.

\section{DIFFERENCES IN RETURNS}

One of the reasons for differences in plan returns may be due to disproportionate costs in both plans, and how returns are affected by expenses that are integral to plan administration. Hustead (1998) indicates that costs of a defined benefit plan ranges from 3.10 of pay in 1996 to 0.23 percent of pay, while costs for defined contribution falls within the range of 1.44 percentage of payroll to 0.16 . Here we find that differences in administrative costs are based on the commitment to both plans. While a defined plan benefit is committed to the promise of a fixed pension upon retirement, a defined contribution plan commits to an annual contribution only. Internal Revenue Service (IRS) regulates the size and tax preferences for plans and their sponsors with regulation that requires adequate funding in the absence of tax abuse. Employment Retirement Income Security Act (ERISA), clearly determines the funding status of defined benefit plans, and plan sponsors are required to pay insurance premiums to the Pension Benefit Guarantee Corporation (PBGC). Watson Wyatt (2007, suggests that data from Form 5500 may not represent a fair comparison, of both plans in terms of the nature of costs that are accounted for in investment income. The data points to the average weighted expense related to mutual funds, and their effect of reducing rates of returns. Supporting this view Watson Wyatt provides data for the period 2006, where 39 percentage points of plan assets for defined contribution plans were invested in mutual funds compared to 10 percentages for defined benefit plans. With such differences, and having 33 percent of mutual fund fees as part of administrative costs, an overall effect is a reduction on defined contribution returns. Therefore, administrative costs charged by investment companies have an important effect on investment rates. Defined contribution plans do not contain a commitment of benefits to be paid upon retirement instead an employer makes contributions based on percentage of an employee's salary while the employee remains in tenure with the employer. The good news for defined contribution plan sponsors is that they do not have the added obligation of paying PBGC premiums since defined contribution funds are not insured.

\section{PRIOR STUDIES OF 401K LOAN PROVISION AND LOAN ACTIVITY}

We looked at another possible factor that may affect the growth of $401(\mathrm{k})$ plans and its associated returns. Prior research indicates that plans offering loan provision increase participation and contribution rates. Therefore an added feature of loan availability may also increase participation and contribution thus increasing plan assets. A General Accounting Office (1997) report noted that pension-plan borrowing increases participation. The study also reported that plans with loan provision show a six percentage point increase over plans without. Results of the study noted that proponents of $401(\mathrm{k})$ borrowings view the privilege as a means to increasing participation where such participation was voluntary. Additionally, proponents see borrowing as having the effect of increased contributions when participants also determine the level of their contributions. The opposing view sees pension borrowing as having the effect of lowering pension income upon retirement. The GAO study also points to interest rates on loans in general that have lower than yields compared to pensions that are not affected by borrowing. The GOA study also showed that for 1988, over 95 percent of $401 \mathrm{k}$ plans with a loan privilege, had at least one participant with an outstanding loan.

We examined data provided by the Employee Benefit Research Institute (EBRI) for years 1998 through 2008 to assess the impact of 401(k) loans on the related assets. Data show that large plans are more likely to have loan features, (Figure 3). The data compares percentage of participants enrolled in plans with loan features, percentage of participants with outstanding loans, and the average loan balance for the respective years. Although there is little variation in percentage of participants enrolled in plans, the EBRI data showed that overall the number of participants with a loan balance ranged between 13 and 18 percentages, and loan balances experienced 1.43 percentage increases to 4.1 percentage decrease. Participants enrolled in plans with loan features ranged between 82 90 percentages. Beshears, Laibson, Choi, and Madrian (2008) concluded that 401 (k) loans may serve as a vehicle 
for increasing "net asset accumulation", which in turn can have a positive impact on participation. Although seen as a possible source of credit, loans from 401 (k) plans do not have a significant effect on wealth accumulation. $\mathrm{Li}$, and Smith (2008) suggests that in calculating loans utilization, a measure of loan balance compared to the maximum loan allowable, 401(k) borrowers used loan availability to a lesser extent than they could. Authors suggest that households could gain from using 401(k) loans. This can be done by "shifting high cost debt" from credit cards and auto loans to $401(\mathrm{k})$ loans.

\section{INVESTMENT STRATEGY AND RISK}

Because of the insignificant impact of investment returns and loan availability on the growth of $401(\mathrm{k})$ plans, we explored whether investment strategy plays a role in investment returns. For the third quarter of 2009, ICI (2010) reported defined contribution assets held $\$ 2622$ billion in mutual funds supporting the view that a large amount of plan assets are held in equity. Employees often express that they are better able to decide on the best investment strategy that maximizes returns and lowers risk on their defined contribution plans. However, Bernheim (1996) describes employees as not having sufficient financial experience to make sound decisions in defined contribution savings plans. Bryne (2004) suggests that defined contribution participants display attitudes to risk portfolio that differ from accepted investment principles. Part of this finding may be due to a perception that management of an employees' portfolio is more left to fund managers. Bernartzi and Thaler (1999), found that investors appear to experience "myopic loss aversion' where investors avoid short-term losses although long term planning is central to retirement. Their results show that participants appear to use a more conservative approach towards equity, when compared to other participants. However, in their 2002 study Bernartzi and Thaler also found that there was a high ratio of equity funds when compared to bond funds, and participants were inclined to have a preference of higher than average allocations to equities. Such preferences in investment strategy bear a direct dependence on market performance and do have a significant impact when there is a downward trend in market conditions. Employees often hold investments in an employer's equity plan. The case of Enron is mostly as an example of the effects of investing in an employer's equity. Enron's employees invested almost 58 percentage points of 401(k) assets in the company's stock. Most of the equity was lost to the bankruptcy filings of Enron. Benartzari and Thaler (2001) also suggest that this happens when plan sponsors essentially have more equity funds in portfolios, and participants will then naturally chose from those available funds when presented with options. Watson Wyatt (2007) supports the view that asset allocation whether by a plan participant or strategies of the plan sponsor, does serve as an important determinant on the success of plans. In general, workers who have an advantage in age, education, and are risk averse, do seem to allocate more equity to defined contribution portfolios. Watson Wyatt lends support and compares these findings to their analyses of asset allocations in defined contribution plans. Accordingly, participants who do not have the benefit of a defined benefit plan and are therefore dependent on a defined contribution plan need more guidance in making asset allocation decisions. Madarin and Shea (2001) concludes that new cohorts in their study had 80 percent of contributions allocated to money market, and 16 percentage invested in stock funds. Old cohorts on the other hand allocate approximately 70 percentage of $401(\mathrm{k})$ contributions to stock funds (equity) while less than 10 percentage is allocated to money market funds, and 90 percentage of participants are likely to invest in equity while less than 20 percentage age are likely to invest in money market funds. This pattern indicates that more seasoned employees may have more experience with equity allocations and are therefore less risk averse. Benartzi and Thaler (2001) suggest that investor increases in equity investments may be attributed to new equity funds available in the bull markets of the 1990s, their concern was for the design of retirement savings plan, and whether age should be factored in the design.

\section{DISCUSSION}

Investment returns on $401(\mathrm{k})$ plans do not exceed returns on defined benefit plans for the period investigated. Although plan loans may increase participation, they do have the effect of affecting plans returns in the long run. The rationale used for individuals that defined contributions present them with avoidance of longevity risks faced by defined benefit plans does not find support in investment returns. A determining factor on $401(\mathrm{k})$ plan returns is the gap between participant loan rate of interest, and plan rate of interest, and whether or not participants continue to make contributions during the loan repayment period (GOA, 1997). Weese (2009) suggests that there are advantages of a 401(k) loan such as a reduction of interest paid to outside lenders. In so doing participants are owners of funds withdrawn as a loan which will eventually is repaid with the accompanying interest. 
An added feature is the low transaction costs. A key finding was that borrowing had the effect of increasing participation for low income employees (GAO 1997). EBRI data 1998-2008, suggests that in general borrowers of 401(k) loans hold less worth, have more outstanding debt, and have less family income than those who do not borrow. (EBRI, 2009). A key finding of the GAO 1997 study shows that borrowing had the effect of increased participation particularly for low income employees and plans that feature a loan provision had an average increase of 35 percentage contribution rate compared to plans that do not allow borrowing. Less than eight percentage of participants had loans outstanding and borrowers were mostly minorities who could not borrow from other financial institutions or other workers covered by other pension plans (GOA, 1997). Studies conducted by EBRI support this finding where percentage of participants with outstanding loans shows very little variation from year to year. The US Department of Labor (1994) data also supports previous findings that loans tend to be a small amount of plan assets, and a small percentage of loans are converted into distributions for any given year.

\section{THE PORTABILITY EFFECT}

The portability factor in defined contribution plans is an important step that influences preference of the plan. It is seen as an important step that allows employees to transfer payments from defined contribution distributions into Individual Retirement Accounts (IRA) accounts through a rollover feature. Most employees see this tax-free feature of rollovers as a significant factor in the portability of their defined contribution plans, where employees move their 401(k) plans from one employer to the next. Data from ICI (2010) lends support and show that as of 2007, rollovers accounted for $\$ 323$ billion, a significant portion of flows into traditional IRAs. Employers also benefit where this portability feature frees them of the burden of monitoring the retirement funds left in a previous employer's plan. Portability does have its costs. In applying the rules of ERISA, fiduciary obligation was removed from the employer and transferred to the employee under a defined contribution plan which accelerated the trend in defined contribution and its eventual growth. The defined contribution plan while allowing for portability, also entails longevity risk, which can be minimized by the use of annuity, and fluctuations or volatility on investment returns are all borne by employees. Gale, Iwry and Orszag (2005) notes that the results of the roll over feature allows for expansion of portable "low cost accounts" to individuals who for one reason or another do not have an IRA, but were covered by an employer's plan for a period. Quick (1999) suggests that the primary motivation for plan choice from defined benefit to a defined contribution, is a match of worker characteristics with those of a plan. We cannot deny that our society is comprised of a high degree of employee mobility, and a significant factor contributing to the current trend toward defined contribution plans is the fact that employees are convinced that the option of moving from one firm to the next and having the privilege of rolling over funds accumulated to another plan or an IRA is a better option than longevity risk with an uncertain future in a defined benefit plan. The sense of being in charge of one's destiny as opposed to being determined by a trustee adds to the appeal.

\section{LONGEVITY REWARDS}

What if any are the rewards of the defined contribution plan? We could argue that on the surface, that it is the potential returns that an individual hopes to realize. This is only possible under good market conditions. We find in the data from the Watson Wyatt study that defined benefit plans out performed defined contribution plans for years $1996-2006$.

The reality of rewards is illusive by nature. An important determinant of returns is market conditions. Under the defined contribution plan model, employees assume the fiduciary role in planning for retirement. This shifting of responsibility leaves the employee with only one alternative; which is dependence on the financial industry services. Having to rely on the experts in this industry the investing employee has no other choice but to embrace their advice and products. This situation is evident in model of the $401 \mathrm{~K}$ plan with its attractive employer matching feature since the $1980 \mathrm{~s}$.

\section{CONCLUSION}

In analyzing the various studies that have addressed the growth of defined contribution we do not find plans returns to have significant influence. Loan availability although utilized, is not significant. Investment strategy as 
employed by employees, clearly requires taking advantage of any and all avenues of financial education. The results of plan returns analyzed in this study points to the reality of this fact. So how can we as a society overcome this hurdle? Parker (2001) suggests that with the ever increasing growth rate of defined contribution plans, which are mostly invested in the stock market, any gains realized tend to distort traditional investment patterns. Investment experts concerned about the retirement crisis suggest that individuals such as holders of individual accounts, who typically invest in stocks, usually make purchases during their peak earning years. Upon retirement, stocks are sold to realize liquidity, and when this happens Parker suggests we will be on a collision course where stock prices decline for many years to come, and the so called artificial wealth created will disappear plunging the economy into a depression. This situation became evident when our economy experienced the market during the last two years. Managed wealth as is the case with the defined contribution plans, is within the control of large institutional investors who are measured on the basis of their performance. Parker (2001) notes that a very important fact overlooked in this measurement of performance is the fact that securities are subject to two kinds of returns. For the most part, investors look forward to those returns in the form of dividends, and also exogenous returns which are based on trader perception of future company profitability as well as other variables interacting within the external environment. Zall (2000) sees the main reason attributing to under savings for retirement as inaccurate forecasting of longevity. In assessing the growth of defined contribution plans it is well noted that more regulations forced employers to adopt the more flexible defined contribution that allowed employees to take control of their retirement funds. Supporters of the defined contribution plan, advocate that although the defined benefit plan may appear to have the promise of a more certain future with regard to risk, it is no more risk free than defined contribution plans. The difference here is that with the defined benefit, the risk is borne by both employer and employee. The reality for the employee is that promised funds may not be there upon retirement. The management of investment funds requires expert knowledge which most employees do not have or cannot afford. Financial companies who market their products, for individual accounts, may be more interested in making a profit as opposed to ensuring that future retirees reap the rewards of the "so called", portability effects of the defined contribution plan.

\section{AUTHOR INFORMATION}

Beverley Hollingsworth (bholling@fsc.edu) is an Assistant Professor of Business at Fitchburg State University. She received her Ph.D. from Walden University. Her current research interests include Accounting and Foreign Direct Investment.

Wei Wang is a graduate student at Fitchburg State University in the MBA - Accounting Track. He plans to receive his degree in October 2010. He holds a bachelor's degree in International business and economics from Tianjin Polytechnic University in China. He is the son of Wenyong Wang and Hua Wang. Wei hopes to return to his home in China after earning his $\mathrm{PhD}$ in the United States

\section{REFERENCES}

1. Andrews, A. (1992). The Growth and Distribution of 401(k) Plans. Trends in Pensions 1992, ed. John and Daniel J. Beller, 149-76. Washington D. C.: U.S. Department of Labor, Pension and Welfare Benefits Administration.

2. Bernartzi and Thaler (1999). Risk Aversion or Myopia, Management Science, vol 45, 3, 364-381)

3. Benartzi, S., \& Thaler, R. (2001). Naïve Diversification Strategies in Defined Contribution Savings Plans. American Economic Review, 91, (1): 79-98.

4. Benartzi, S, \& Thaler, R. (2002). How much is Investor Autonomy Worth? The Journal of Finance, Vol 57, University of California-Los Angeles Working Paper.

5. Bernheim, D. (1996). Financial Illiteracy, Education, and Retirement Saving. University of Pennsylvania (Pension Research Council) Working Paper No 96-7.

6. Beshears, J., Choi, J., Laibson, D., \& Madrain, B. (September, 2008) Financial Liquidity and Saving: Evidence from 401 (k) Loans. Available at www.hsph.harvard.edu/pgda/events/.../2009/Loans_Madrian_Fall2008.pdf

7. Bryne, Alistair. (October, 2004) Investment Decision Making in Defined Contribution Pension Plans. Pensions, An International Journal, Vol, 10, 1, 37-49. 
8. Choi, J. Laibson, D., Madrian, B. \& Metrick, A. (2002) Defined Contribution Pensions: Plan Rules, Participant Choices, and the Path of Least Resistance. Tax Policy and the Economy, Vol 16, pp.67-113: MIT Press Cambridge, MA

9. Clark, R, Goodfellow, Schieber, S., \& Warwick, D, (1999). Making the most of 401 (k) Plans: Who's Choosing What and Why? In Forecasting Retirement Needs and Retirement Wealth, edited by Brett Hammond, Olivia S. Mitchell, and Anna Rapport, Philadelphia: University of Pennsylvania Press.

10. Clark, R., McDerermed, A., \& Trawich, M. (1994). Firm Choice of Type of Pension Plan: Trends and Determinants., in The Future of Pensions in the United States., ed. By Ray Schmitt. Philadelphia:

University of Pennsylvania Press. Pp. 115-125.

11. Engen, E., Gale, W., Scholz, J. 1996b). The Illusionary Effects of Saving Incentives on Saving. Journal of Economic Perspectives. 10 940: 113-138.

12. Gale, W. G, Papke, L.E, \& VanDerheri, J. (September, 1999). Understanding the Shift from Defined Benefit to Defined Contribution Plans. Paper presented at a conference entitled "ERISA After 25 years: A Framework for Evaluating Pension Reform" and convened by the Brookings, the Stanford Institute for Economic Policy Research, and the TIAA-CREF Institute at the National Press Club on September 17, 1999.

13. Gale, W., Iwry. M., and Orszag, P. (March, 2005). The Automatic 401 (k): A Simple Way To Strengthen Retirement Saving. Tax Notes. 1207-1214.

14. General Accounting Office, (Oct 1997). 401k Pension Plans: Loan Provisions Enhance Participation. But may affect Income Security for Some. United States General Accounting Office., GOA, HEHS-98-5, Washington D.C..

15. Holden, S, \& VanDerhei, J. (February, 2001).401 (k) Plan Asset Allocation, Account Balances, and Loan Activity in 1999. Issue Brief, (230), EBRI.

16. (November, 2001). 401(k) Plan Asset Allocation, Account Balances, and Loan Activity in 2000. Issue Brief (239), EBRI.

17. _ (September, 2003). 401(k) Plan Asset Allocation, Account Balances, and Loan Activity in 2002. Issue Brief \#261), EBRI.

18. (August, 2004). 401(k) Plan Asset Allocation, Account Balances, and Loan Activity in 2003. Issue Brief (272), EBRI.

19. (September, 2005). 401 (k) Plan Asset Allocation, Account Balances, and Loan Activity in 2004. Issue Brief (285), EBRI.

20. _. (August, 2006). 401 (k) Plan Asset Allocation, Account Balances, and Loan Activity in 2005. Issue Brief (296), EBRI.

21. Hustead, E. (1998). Trends in Retirement Income Plan Administrative Expenses In Living with Defined Contribution Pension: Remaking Responsibility, edited by Olivia S. Mitchell and Sylvester J. Schieber. Philadelphia: University of Pennsylvania Press.

22. Investment Company Institute. (February, 2010). The U.S Retirement Market, Third Quarter 2009. Washington DC. Vol 18, no. 5- Q3. Available at www. Ici.org/pdf.fm-v18n5.pdf

23. Kruse, D. (1995). Pension Substitution in the 1980s: Why the Shift Toward Defined Contributions? Industrial Relations. 34, (2): 218-241.

24. Li,G, and Smith, P (2008-42) Borrowing from Yourself:401k Loans and Household Balance Sheets). Finance and Economics Discussion Series, Division of Research \& Statistics and Monetary Affairs, Federal Reserve Board, Washington, D.C.

25. Mandrian, B. \& Shea, D. F (November, 2001). The Power of Suggestion: Inertia in 401K Participation and Savings Behavior. Quarterly Journal of Economics. (4) 1149-1187.

26. Munnell, A.H, Golub-Sass, .F, Soto, M., \& Vitaglino, F. ( March, 2006). Why are healthy employers freezing their pensions? Retrieved September 23, 2006, from Boston College web site: Center for Retirement Research at Boston College http//www.bc.edu/center/crr/ib 56.shtml

27. Munnell, A,\& Perun, P. (August, 2006). An Update on Private Pensions. Issue in Brief, (50) Center for retirement Research at Boston College

28. Papke, L E. (Spring, 1995). Participation in and Contributions to 401K Pension Plans. Journal of Human Resources, 30 (2): 311-325.

29. Papke. L. (Spring, 1999). Are 401k Plans Replacing Other Employer-Provided Pensions? Evidence from Panel Data. Journal of Human Resources, 34 (2): 346-368 
30. Parker, T. (March-April 2001). The coming retirement crisis. Financial Executive. 42-45.

31. Quick, C. (July, 1999). An Overview of Cash Balance Plans. EBRI Notes. 20 (7).

32. U.S Department of Labor (2008c). Employee Benefits Security Administration. Private Pension Plan Bulletin Tables. Washington DC.

33. U.S. Department of Labor. (1994). Pension Coverage Issues for the 90s. United States Government Printing Office. Washington D.C..

34. U.S. Government Accounting Office. (October, 1997). 401 (k) Pension plans Loan Provisions Enhance Participation, But May Affect Income Security for Some. Letter Report, GOA-HEHS-98-5 Washington DC. Available at www.goa/archive/1998/he98005.pdf

35. VanDerhei, J., Holden, S., Copeland, C., \& Alfonso, L. (August, 2007). 401(K) Plan Asset Allocation, Account Balances and Loan Activity in 2006. Issue Brief (308), EBRI.

36. _ (December, 2008). 401 (k) Plan Asset Allocation, Account Balances, and Loan Activity in 2007. Issue Brief (324), EBRI.

37. VanDerhei, J., Holden, S., \& Alfonso, L. (October, 2009). 401 (k) Plan Asset Allocation, Account Balances, and Loan Activity in 2008. Issue Brief (235), EBRI.

38. Watson-Wyatt Insider. (June, 2008). Defined Benefit vs. 401(k) Plans: Investment Returns for 2003-2006. Watson Wyatt Insider.

39. Weese, D. (May, 2009) Rethinking Conventional Wisdom About 401(k) Loans.

Figure 1 - Plan Weighted Median Rates of Return

\begin{tabular}{|c|c|c|c|c|}
\hline Year & Number of sponsors & DB Plan & 401(k) plan & Difference \\
\hline 2006 & 914 & $12.90 \%$ & $11.34 \%$ & $1.56 \%$ \\
\hline 2005 & 2,584 & $7.74 \%$ & $6.69 \%$ & $1.05 \%$ \\
\hline 2004 & 2,583 & $11.81 \%$ & $9.80 \%$ & $2.01 \%$ \\
\hline 2003 & 2,514 & $21.35 \%$ & $19.68 \%$ & $1.67 \%$ \\
\hline 2002 & 2,085 & $-8.56 \%$ & $-10.93 \%$ & $2.37 \%$ \\
\hline 2001 & 2,239 & $-3.78 \%$ & $-6.07 \%$ & $2.29 \%$ \\
\hline 2000 & 2,058 & $-0.01 \%$ & $-2.76 \%$ & $2.75 \%$ \\
\hline 1999 & 1,472 & $13.46 \%$ & $14.41 \%$ & $-0.95 \%$ \\
\hline 1998 & 2,958 & $14.25 \%$ & $15.29 \%$ & $-1.04 \%$ \\
\hline 1997 & 2,931 & $18.82 \%$ & $19.73 \%$ & $-0.91 \%$ \\
\hline 1996 & 3,034 & $14.53 \%$ & $14.10 \%$ & $-0.43 \%$ \\
\hline 1995 & 3,063 & $21.10 \%$ & $19.20 \%$ & $1.90 \%$ \\
\hline Average & & $10.30 \%$ & $9.21 \%$ & $1.09 \%$ \\
\hline
\end{tabular}

Source: Watson Wyatt 2007

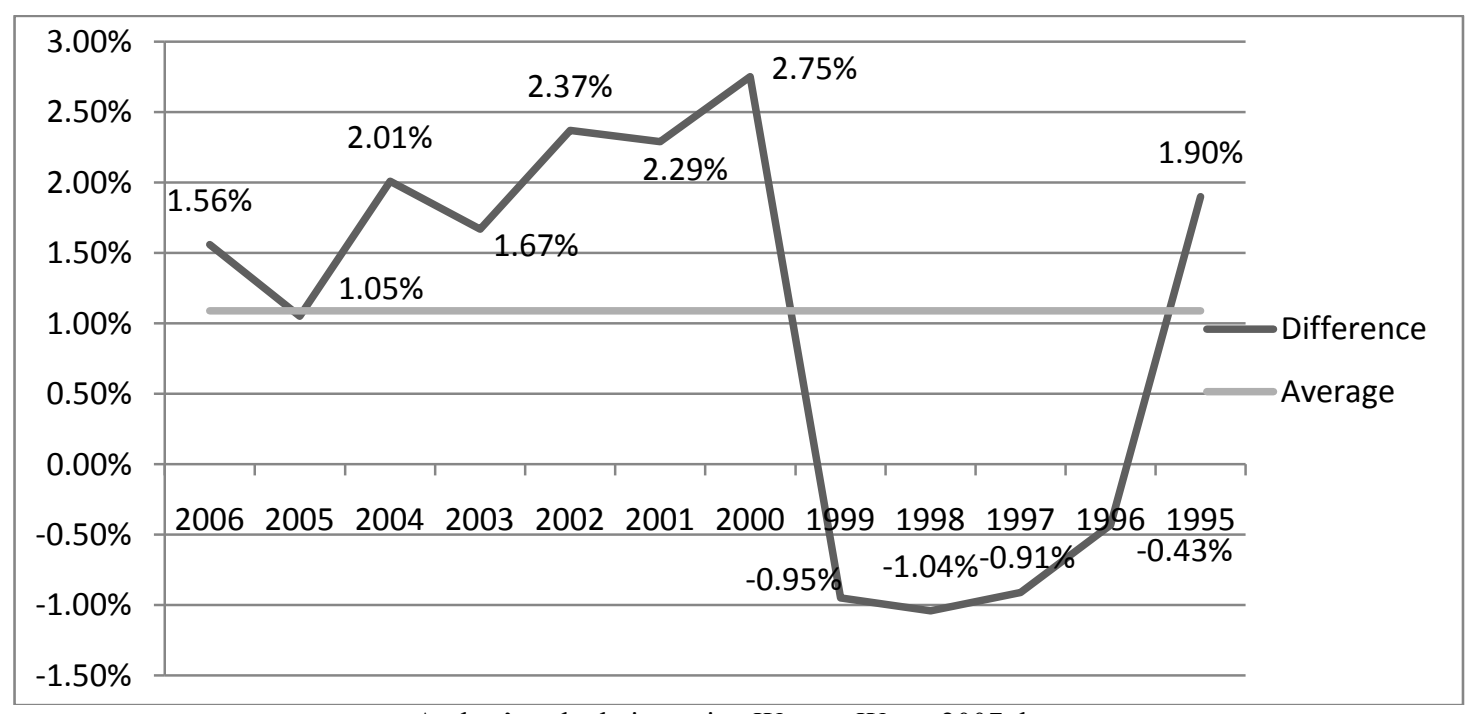

Author's calculation using Watson Wyatt 2007 data 
Figure 1a - Largest One Sixth Plans

\begin{tabular}{|c|c|c|c|}
\hline Year & DB Plan & $\mathbf{4 0 1 ( k ) \text { plan }}$ & Difference \\
\hline 2006 & $12.53 \%$ & $11.20 \%$ & $1.33 \%$ \\
\hline 2005 & $7.20 \%$ & $6.53 \%$ & $0.67 \%$ \\
\hline 2004 & $10.60 \%$ & $9.48 \%$ & $1.12 \%$ \\
\hline 2003 & $20.65 \%$ & $19.07 \%$ & $2.48 \%$ \\
\hline 2002 & $-8.73 \%$ & $-11.21 \%$ & $2.00 \%$ \\
\hline 2001 & $-4.10 \%$ & $-6.10 \%$ & $2.67 \%$ \\
\hline 2000 & $-0.32 \%$ & $-2.99 \%$ & $-2.97 \%$ \\
\hline 1999 & $13.11 \%$ & $16.08 \%$ & $-1.02 \%$ \\
\hline 1998 & $13.68 \%$ & $14.70 \%$ & $-0.30 \%$ \\
\hline 1997 & $18.74 \%$ & $18.44 \%$ & $-1.47 \%$ \\
\hline 1996 & $14.30 \%$ & $12.83 \%$ & $4.89 \%$ \\
\hline Average & $23.18 \%$ & $18.29 \%$ & $1.21 \%$ \\
\hline
\end{tabular}

Source: Watson Wyatt 2007

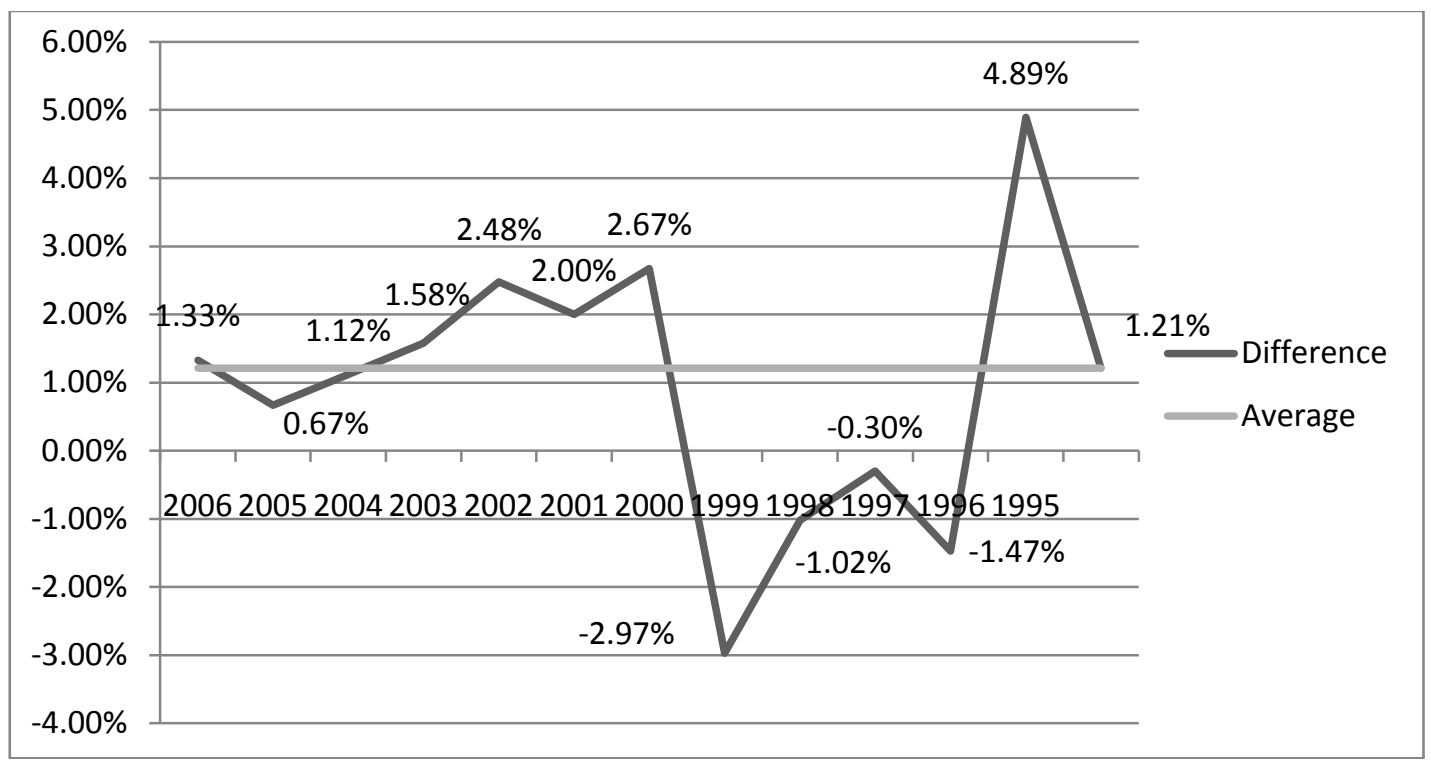

Author's calculation using Watson Wyatt 2007 data 
Figure 2 - Largest One Half Plans

\begin{tabular}{|c|c|c|c|}
\hline Year & DB Plan & 401(k) plan & Difference \\
\hline 2006 & $11.98 \%$ & 11.39 & $0.59 \%$ \\
\hline 2005 & $6.72 \%$ & $6.61 \%$ & $0.11 \%$ \\
\hline 2004 & $9.78 \%$ & $9.39 \%$ & $0.39 \%$ \\
\hline 2003 & $18.95 \%$ & $19.53 \%$ & $-0.58 \%$ \\
\hline 2002 & $-8.60 \%$ & $-11.83 \%$ & $3.23 \%$ \\
\hline 2001 & $-3.94 \%$ & $-6.77 \%$ & $2.83 \%$ \\
\hline 2000 & $-0.32 \%$ & $-3.40 \%$ & $3.08 \%$ \\
\hline 1999 & $11.87 \%$ & $15.32 \%$ & $-3.45 \%$ \\
\hline 1998 & $13.37 \%$ & $14.62 \%$ & $-1.25 \%$ \\
\hline 1997 & $17.87 \%$ & $17.97 \%$ & $-0.30 \%$ \\
\hline 1996 & $14.30 \%$ & $12.83 \%$ & $-0.10 \%$ \\
\hline 1995 & $21.54 \%$ & $17.63 \%$ & $3.91 \%$ \\
\hline Average & $9.43 \%$ & $8.61 \%$ & $0.82 \%$ \\
\hline
\end{tabular}

Source: Watson Wyatt 2007

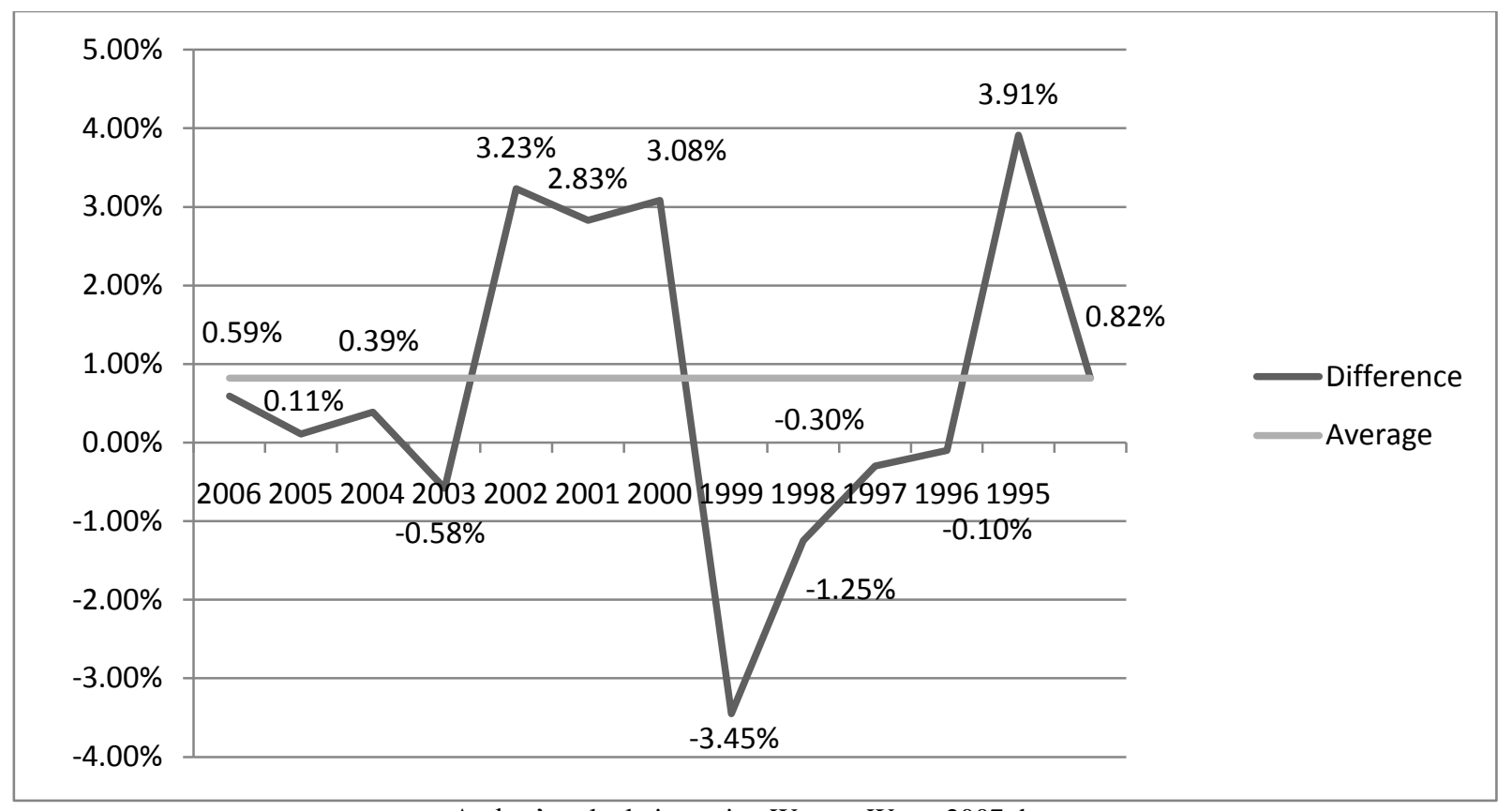

Author's calculation using Watson Wyatt 2007 data 
Figure 2a - Smallest One Sixth Plans

\begin{tabular}{|c|c|c|c|}
\hline Year & DB Plan & $\mathbf{4 0 1}(\mathbf{k})$ plan & Difference \\
\hline 2006 & $10.12 \%$ & $11.59 \%$ & $-1.47 \%$ \\
\hline 2005 & $5.42 \%$ & $6.59 \%$ & $-1.59 \%$ \\
\hline 2004 & $7.64 \%$ & $9.23 \%$ & $-4.95 \%$ \\
\hline 2003 & $14.70 \%$ & $19.65 \%$ & $4.31 \%$ \\
\hline 2002 & $-8.02 \%$ & $-12.33 \%$ & $3.92 \%$ \\
\hline 2001 & $-3.51 \%$ & $-7.43 \%$ & $6.60 \%$ \\
\hline 2000 & $-1.43 \%$ & $-5.17 \%$ & $-7.11 \%$ \\
\hline 1999 & $9.00 \%$ & $16.11 \%$ & $-3.58 \%$ \\
\hline 1998 & $9.87 \%$ & $13.45 \%$ & $-3.76 \%$ \\
\hline 1997 & $12.67 \%$ & $16.43 \%$ & $-1.79 \%$ \\
\hline 1996 & $10.63 \%$ & $12.42 \%$ & $-1.76 \%$ \\
\hline 1995 & $15.18 \%$ & $16.94 \%$ & $-1.03 \%$ \\
\hline
\end{tabular}

Source: Watson Wyatt 2007

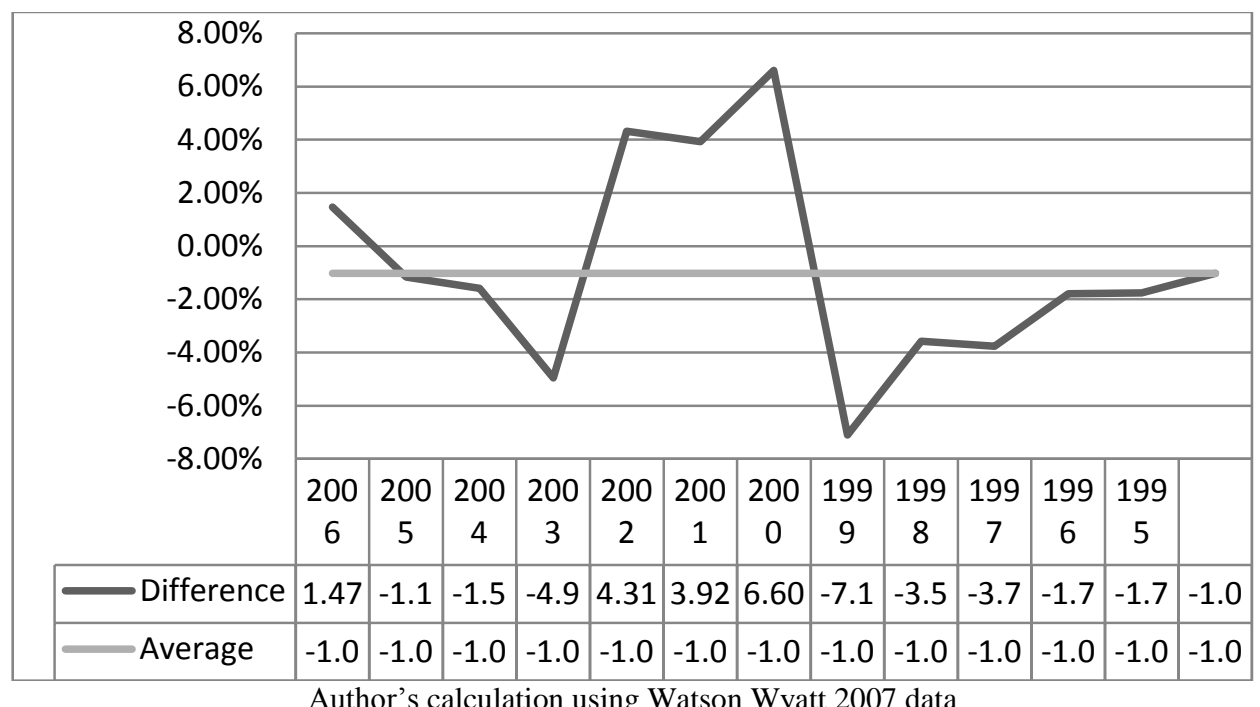


Figure 3

\begin{tabular}{|c|c|c|c|c|}
\hline Year & $\begin{array}{c}\text { Participant Enrolled in Plans } \\
\text { with Loan Features }\end{array}$ & \% with Loans & $\begin{array}{c}\text { Avg. Loan } \\
\text { Balance }\end{array}$ & $\begin{array}{c}\text { Loan Balance as a Percentage of } \\
\text { Account Balances }\end{array}$ \\
\hline 2008 & $88 \%$ & $18 \%$ & 7,191 & $16 \%$ \\
\hline 2007 & $90 \%$ & $18 \%$ & 7,495 & $12 \%$ \\
\hline 2006 & $85 \%$ & $18 \%$ & 7,292 & $12 \%$ \\
\hline 2005 & $85 \%$ & $19 \%$ & 6,821 & $13 \%$ \\
\hline 2004 & $87 \%$ & $19 \%$ & 6,946 & $13 \%$ \\
\hline 2003 & $86 \%$ & $18 \%$ & 6,839 & $16 \%$ \\
\hline 2002 & $84 \%$ & $17 \%$ & 6,659 & $14 \%$ \\
\hline 2001 & $84 \%$ & $18 \%$ & 6,644 & $14 \%$ \\
\hline 2000 & $83 \%$ & $18 \%$ & 6,856 & $14 \%$ \\
\hline 1999 & $82 \%$ & $18 \%$ & 6,815 & $14 \%$ \\
\hline 1998 & $88 \%$ & $16 \%$ & 6,717 & \\
\hline
\end{tabular}

Source: EBRI 1998 - 2008

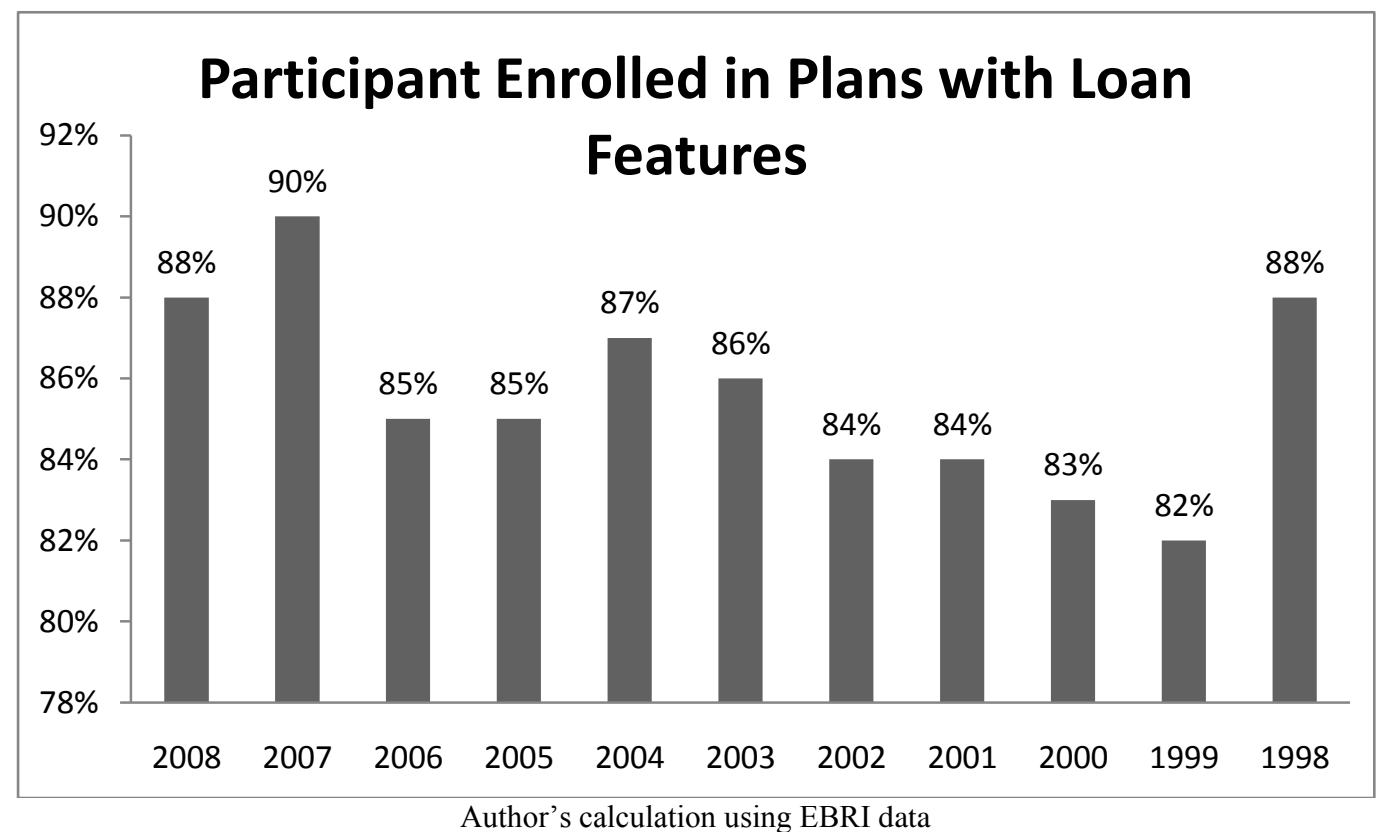

Author's calculation using EBRI data

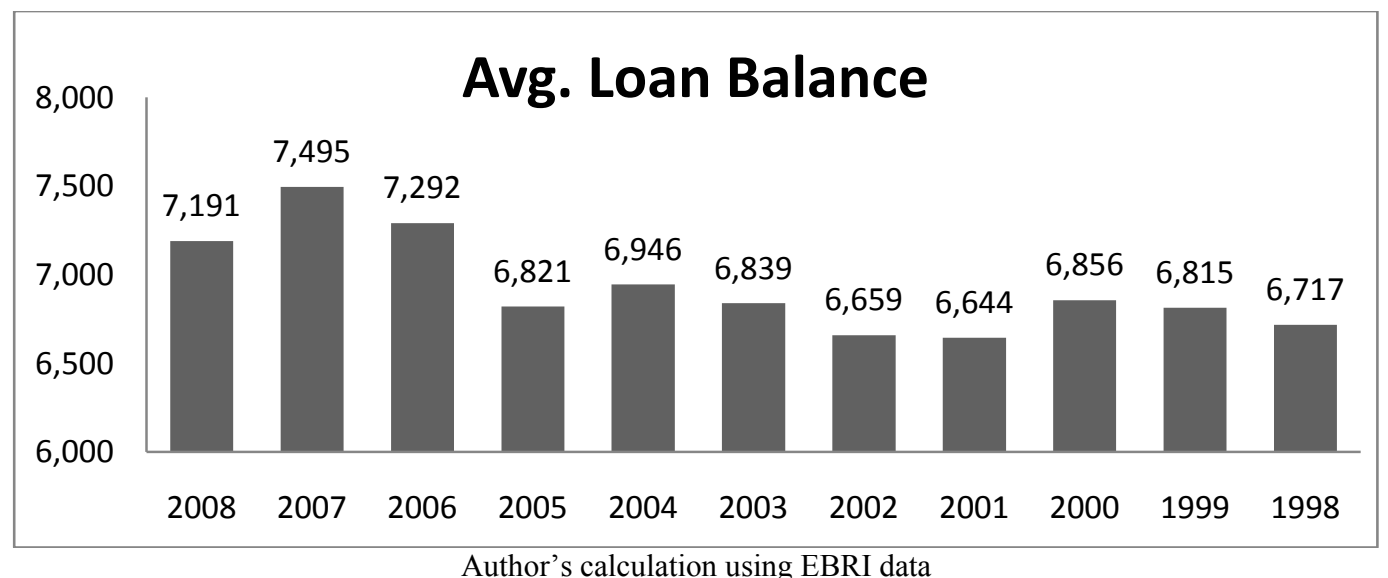

Author's calculation using EBRI data 
Figure 3a

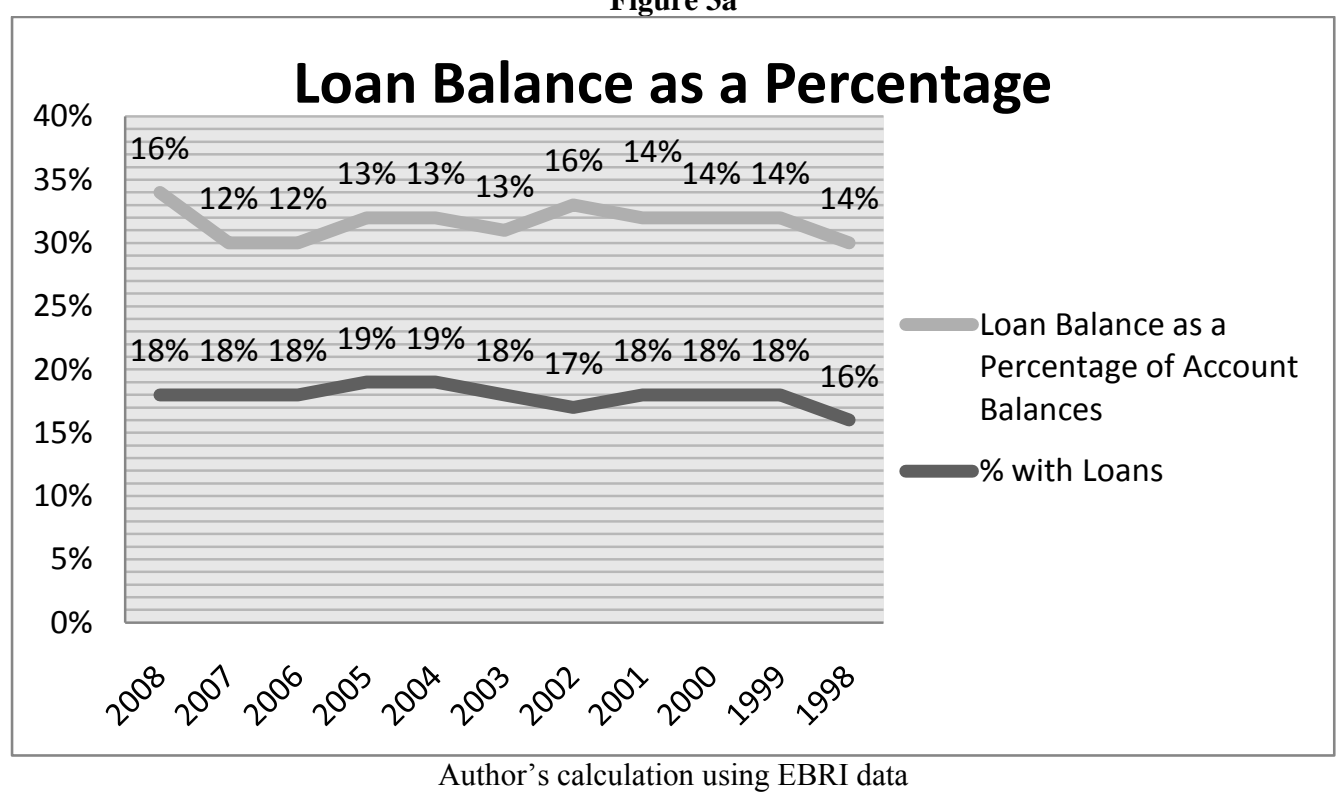

Author's calculation using EBRI data 
NOTES 